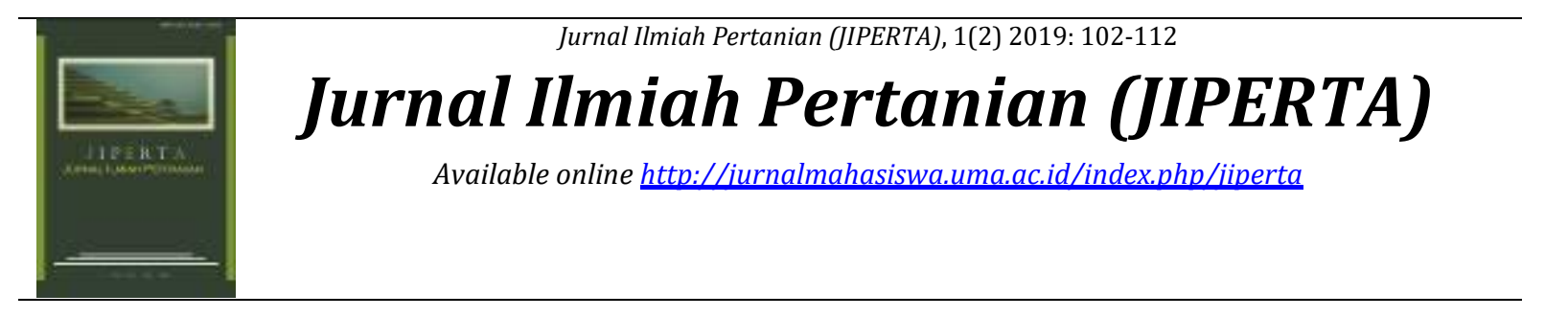

\title{
Efektivitas Aplikasi Kompos Kulit Kopi dan Fungi Mikoriza Arbuskular) Terhadap Produktivitas Jagung Manis
}

\section{Effectifity Of Coffee Skin Compost and Arbuscular Mycorrhizal Fungi Application on Sweet Corn Productivity}

\begin{abstract}
Hary Sahputra1), Suswati2), Gusmeizal ${ }^{3) *}$
1) Program Studi Agroteknologi, Fakultas Pertanian, Universitas Medan Area, Indonesia

Abstrak

Jagung menempati posisi penting dalam perekonomian nasional, khususnya untuk mendukung perekonomian Sumatera Utara. Studi ini bertujuan untuk mendapatkan data tentang kemampuan kompos yang berasal dari kulit kopi dan fungi mikoriza arbuskular terhadap pertumbuhan dan produksi tanaman jagung manis (Zea mays sccharata Sturt). Metode yang digunakan dalam penelitian ini adalah Racangan Acak Kelompok (RAK) secara faktorial, dengan 2 (dua) faktor perlakuan, yakni kompos kulit kopi dan fungi mikoriza arbuskular. Parameter yang diamati adalah tinggi tanaman, jumlah daun, panjang tongkol, produksi tanaman sampel per plot, produksi tanaman per plot, bobot basah bagian atas, bobot basah bagian bawah, persentase serangan OPT, kolonisasi fungi mikoriza arbuskular, efektivitas aplikasi perlakuan terhadap semua parameter. Hasil yang diperoleh dari penelitian ini adalah Pemberian kompos kulit kopi tidak berpengaruh nyata terhadap seluruh parameter pengamatan. Kombinasi kompos kulit kopi dan fungi mikoriza arbuskular tidak berpengaruh nyata terhadap parameter pengamatan tinggi tanaman, jumlah daun, panjang tongkol, produksi tanaman sampel per plot, produksi tanaman per plot, bobot basah bagian atas dan bobot basah bagian bawah.
\end{abstract}

Kata Kunci: Efektifitas, mikoriza, produtivitar, kolonisasi

\begin{abstract}
Corn is one of stupple food to support economic growth in North Sumatera. The purpose of this research was to obtain data on the ability of compost derived from coffee husks and arbuscular mycorrhizal fungi in the growth and production of sweet corn plants (Zea mays sccharata Sturt). The method used in this study is a randomized block design (RDB) in factorial, with 2 (two) treatment factors, namely: 1) Factor coffee skin and 2) arbuscular mycorrhizal fungi $(M)$, each treatment was repeated two (2) times so that there are 40 experimental plots. The parameters observed are plant height, number of leaves, cob length, sample crop production per plot, crop production per plot, top wet weight, bottom wet weight, percentage of pest attack, colonization of arbuscular mycorrhizal fungi, effectiveness of treatment application to all parameters. The results obtained from this study were: 1) The giving of coffee skin compost did not significantly affect the parameters of plant height, number of leaves, cob length, sample plant production per plot, crop production per plot, top wet weight and bottom wet weight; 2) The allocation of arbuscular mycorrhizal fungi has no significant effect on the parameters of observing plant height, number of leaves, cob length, sample plant production per plot, crop production per plot, top wet weight and bottom wet weight; 3) The combination of coffee husks compost and arbuscular mycorrhizal fungi did not significantly affect the parameters of plant height, number of leaves, length of cob, sample crop production per plot, crop production per plot, top wet weight and bottom wet weight.
\end{abstract}

Keywords: Efektifitas, mikoriza, produtivitar, kolonisasi

How to Cite: Hary S, Gusmeizal \& Suswati (2020) Efektivitas aplikasi kompos kulit kopi dan Fungi mikoriza arbuskular) terhadap produktivitas jagung manis. Jurnal Ilmiah Pertanian (JIPERTA), 6 (2): 106-111

*E-mail: sahputra97@gmail.com 
Hary Sahputra, Suswati \& Gusmeizal, Suswati (2020) Efektivitas aplikasi kompos kulit kopi dan Fungi mikoriza arbuskular) terhadap produktivitas jagung manis

\section{PENDAHULUAN}

Jagung manis (Zea mays saccharata Sturt) adalah tanaman pangan yang kebutuhan setiap tahunnya meningkat sehubungan dengan pertambahan penduduk yang senang mengkonsumsinya (Reavindo \& Bangun, 2016; Setya dkk., 2019 ; Permadi dkk., 2019). Jagung menempati posisi penting dalam perekonomian nasional, khususnya untuk mendukung perekonomian Sumatera Utara, karena merupakan sumber karbohidrat sebagai bahan baku industri pangan, pakan ternak unggas dan ikan (Andi, 2013). Menurut Badan Pusat Statistik pada tahun 2016, produksi jagung manis mencapai 19,6 juta ton dengan luas lahan 4,8 juta hektar. Sedangkan di tahun 2015, produksi jagung manis mencapai 23,6 juta ton dengan luas lahan 3,79 hektar. Dari data diatas terjadi fluktuasi yang salah satu penyebabnya adalah kurangnya bahan organik tanah dan banyaknya serangan organisme pengganggu tanaman (OPT). Adapun organisme pengganggu tanaman yang menyerang tanaman jagung manis adalah penggerek batang jagung (O. furnacalis), ulat tongkol (Helicoverpa armigera), kutu daun (Rhopalosiphum maidis), bulai (Peronosclespora maydis), hawar daun (Helminthosporium turcicum), layu Stewart (Pantoea stewartii). Penurunan produksi yang diakibatkann organisme pengganggu tanaman pada jagung manis mencapai 15 - $35 \%$ (Andi,2013).

Pada umumnya, kandungan bahan organik tanah pada lahan pertanian di Indonesia tergolong rendah berkisar 3 - 5 \% (Hanafiah, 2015). Bahan organik merupakan sumber nutrien inorganik bagi tanaman dan memiliki peran penting untuk menciptakan kesuburan tanah. Peranan bahan organik bagi tanaman adalah menyediakan zat tumbuh dan vitamin yang dapat diserap langsung oleh tanaman untuk merangsang pertumbuhan tanaman. Salah satu limbah pertanian yang memungkinkan untuk digunakan dalam pembuatan kompos adalah kulit kopi. Limbah padat kulit kopi ini memiliki kadar bahan organik dan unsur hara yang dapat memperbaiki struktur tanah Manullang dkk, 2017). Menurut Sukrisno (2013) buah kopi terdiri dari 55,4\% biji kopi, 28,7\% kulit buah (pulp), 11,9\% kulit cangkang dan 4,9 \% lendir kering. Berdasarkan data Badan Pusat Statistik (BPS) Sumatera Utara (2018) luas perkebunan kopi pada tahun 2017 seluas 6.269 hektar dengan produksi kopi sebesar 3.602 ton dan menghasilkan limbah kulit buah kopi sekitar 1.980 ton. Limbah kulit buah kopi tersebut dapat dimanfaatkan sebagai pupuk organik, sehingga mengurangi pencemaran dan menjadi salah satu solusi dalam permasalahan penggunaan pupuk anorganik (Muryanto dkk., 2005).

Berdasarkan Pusat Penelitian Kopi Kakao (2004) kadar C-organik kulit buah kopi adalah 4,53\%, kadar nitrogen 2,98\%, fosfor $0,18 \%$ dan kalium 2,26\%. Selain itu kulit buah kopi juga mengandung unsur $\mathrm{Ca}, \mathrm{Mg}, \mathrm{Mn}, \mathrm{Fe}, \mathrm{Cu}$ dan $\mathrm{Zn}$. Hasil analisis yang telah dilakukan oleh Puslitoka tersebut menunjukkan bahwa limbah kulit buah kopi memiliki peluang untuk dimanfaatkan sebagai pupuk organik. Keunggulan kompos kulit kopi adalah bahan baku yang tersedia sangat tinggi dan kandungan yang ada pada kulit kopi yaitu nitrogen $0,18 \%$, fosfor $0,10 \%$ dan kalium $0,52 \%$. Hal ini didukung oleh penelitian Samosir (2018) pemberian kompos kulit buah kopi 10 ton ha-1 dan pupuk NPK $125 \mathrm{~kg}$ 
ha-1 mampu meningkatkan tinggi tanaman, jumlah biji per tanaman, berat biji per tanaman dan hasil per m2 untuk tanaman kedelai (Nubriama dkk., 2019).

Efektivitas adalah suatu tingkat keberhasilan yang dihasilkan oleh seseorang atau organisasi dengan cara tertentu sesuai dengan tujuan yang hendak dicapai. Dengan kata lain, semakin banyak rencana yang berhasil dicapai maka suatu kegiatan dianggap semakin efektif (Nubriama dkk., 2019).

Untuk meningkatkan penyerapan unsur hara pada tanaman jagung manis, maka aplikasi kompos kulit kopi perlu dikombinasikan dengan aplikasi Fungi Mikoriza Arbuskular (Mardatin, 2002). FMA merupakan bentuk simbiosis mutualisme antara fungi dan sistem perakaran tumbuhan. Setiawati et al. (2005) melaporkan bahwa mikoriza mampu meningkatkan kapasitas tanaman dalam menyerap unsur hara dan air, ketahanan terhadap kekeringan, sebagai kontrol biologi, melindungi tanaman dari logam-logam berat dan dari serangan patogen akar serta dapat membantu pertumbuhan tanaman pada kondisi tanah yang kurang memungkinkan. Unsur hara yang dimaksud meliputi N, P, K, Ca dan Mg. Selain itu hasil penelitian Armansyah (2001). menunjukkan bahwa mikoriza banyak memberikan keuntungan bagi tanaman dan tanah, antara lain meningkatkan serapan hara oleh tanaman, bobot kering tanaman, dan hasil pipilan kering jagung. Aplikasi FMA juga dapat mengefisienkan penggunaan pupuk kimia hingga 50\%. Selain itu, FMA juga dapat mengurangi serangan hama dan penyakit pada tanaman. Menurut Suswati et al (2013) aplikasi FMA dapat menghambat perkembangan Blood Disease Bacterium (BDB) dalam jaringan tanaman pisang Barangan. Masa inkubasi BDB pada tanaman bermikoriza yang terserang BDB menjadi lebih panjang yaitu 30 hari setelah tanam (hst) dibanding kontrol (10 hst). Pada studi ini kami melakukan pengujuan Efektivitas Pertumbuhan Dan Produksi Tanaman Jagung Manis (Zea mays saccharata Sturt ) Dengan Aplikasi Kompos Kulit Kopi Dan Fungi Mikoriza Arbuskular"..

\section{METODE PENELITIAN}

\section{Pembuatan Kompos Kulit Kopi}

Untuk mengolah limbah kulit kopi menjadi kompos, bahan yang dibutuhkan adalah kulit buah kopi bagian luar sebanyak $100 \mathrm{~kg}$, 250 g gula merah yang sudah dicacah dilarutkan kedalam 4liter air dan 100 ml EM4. Adapun langkah - langkah pembuatan kompos kulit kopi adalah sebagai berikut dengan menyediakan 100 kg kulit kopi. Selanjutnya dilanjutkan dengan proses dekomposisi. Hasil dekomposisi disiram dengan 100 ml larutan EM4 + gula merah 250 g lalu tutup terpal dengan rapat. Kompos yang sudah masak ditandai dengan perubahan warna bahan organik menjadi kehitaman, bau alkohol/tape selama proses pengomposan hilang.

\section{Persiapan Fungi Mikoriza Arbuskular}

Inokulan FMA mengandung 100 spora untuk setiap $1 \mathrm{~g}$ dan memiliki campuran beberapa spora diantaranya: Glomus sp dan Acaulospora sp. Selanjutnya adalan proses persiapan lahan yang meliputi: permbersihan lahan atau sanitasi, pengelolaan lahan dan 
Hary Sahputra, Suswati \& Gusmeizal, Suswati (2020) Efektivitas aplikasi kompos kulit kopi dan Fungi mikoriza arbuskular) terhadap produktivitas jagung manis

pembuatan bedengan. Bedengan dibuat membentuk plot dengan panjang $120 \times 120 \mathrm{~cm}$ dengan ketinggian $30 \mathrm{~cm}$ dan jarak antar bedengan $50 \mathrm{~cm}$ serta jarak antar ulangan 100 $\mathrm{cm}$. Bedengan dibuat sebanyak 40 bedengan.

\section{Persiapan Benih Jagung Manis}

Benih yang digunakan dalam penelitian ini adalah benih jagung manis varietas Bonanza F1. Penanaman dilakukan dengan cara manual, yaitu dengan menggunakan tugal secara barisan dengan kedalaman tugalan $2 \mathrm{~cm}$ dan pada setiap lubang di isi dengan 2 benih jagung manis varietas Bonanza F1. Setelah itu di tutup dengan tanah. Jarak tanam yang di lakukan adalah 40 x $40 \mathrm{~cm}$. Penetapan tanaman sampel yang terdapat di setiap plot percobaan di tentukan secara acak. Tanaman sampel di tandai dengan patok kayu atau di beri nomor.

\section{Aplikasi Kompos Kulit Kopi}

Kompos kulit kopi di taburkan di atas plot secara merata. Aplikasi kompos dilakukan satu minggu sebelum tanam sesuai dengan dosis yang telah ditentukan.

\section{Aplikasi FMA dan Pemeliharaan Tanaman}

Fungi Mikoriza Arbuskular diaplikasikan pada saat melakukan penanaman benih. Inokulant FMA dimasukkan sesuai dosis perlakuan, selanjutnya bagian atas inokulant FMA di tutupi dengan media tanam setebal $1 \mathrm{~cm}$, selanjutnya benih diletakkan diatas lapisan campuran media tanam. Lalu ditutup dengan lapisan tanah.

Pemeliharaan tanaman meliputi penyiraman, penyiangan gulma, pembumbunan, dan penyisipan benih yang mati.

Pemanenan

Pemanenan dilakukan setelah tanaman berumur 84 hari setelah tanam yaitu pada saat biji jagung manis ditekan mengeluarkan cairan putih seperti susu dan mencapai kriteria panen dengan tanda-tanda daun sudah mulai kering (klobot) berwarna kekuning-kuningan dan rambut tongkol telah berwarna cokelat dan tongkolnya telah berisi penuh. Pemanenan sebaiknya dilakukan pada pagi hari ketika suhu udara masih rendah karena suhu udara yang tinggi dapat mengurangi manis pada biji jagung akibat terjadi konversi gula menjadi pati.

\section{Analisis Data Statistik}

Data statistic diolah dengan kaidah pengujian RAK factorial dua factor dengan dua pengulangan. Parameter yang diuji pasca perlakuan meliputi Tinggi Tanaman (cm), Jumlah Daun (helai), Panjang Tongkol (cm), Panjang Tongkol Tanaman Jagung Manis. Bobot Basah Bagian Atas (shoots), bobot basah bagian atas (shoots), Bobot Basah Bagian Bawah (roots), Produksi Tanaman Sampel Per Plot (g), Produksi Tanaman Per Plot (g).

\section{Kolonisasi FMA}

Persentase kolonisasi dapat diukur dengan perhitungan:

$$
\% \text { kolonisasi akar }=\frac{\text { jumlah akar yang terinfeksi }}{\text { jumlah contoh akar }} \times 100 \%
$$


Sedangkan Intensitas kolonisasi diukur dengan formulasi:

$\mathrm{I}=$ Persentase intensitas kolonisasi FMA

$\mathrm{N}=$ Jumlah keseluruhan akar yang diamati

N1-5 = Jumlah kolonisasi yang ditentukan kelas \% intensitas kolonisasi

Tabel 1. Rangkuman Hasil Sidik Ragam Tinggi Tanaman Jagung Manis Setelah Aplikasi Kompos Kulit Kopi dan Fungi Mikoriza Arbuskular serta Kombinasi Kedua Faktor Perlakuan

\begin{tabular}{|c|c|c|c|c|c|c|c|c|}
\hline \multirow{2}{*}{ SK } & \multicolumn{6}{|c|}{$\mathrm{F}_{\text {Hitung }}$ Tinggi Tanaman } & \multicolumn{2}{|c|}{$\mathrm{F}_{\text {Tabel }}$} \\
\hline & 2 MST & 3 MST & $4 \mathrm{MST}$ & $5 \mathrm{MST}$ & $6 \mathrm{MST}$ & $7 \mathrm{MST}$ & $\mathrm{F}_{0,05}$ & $\mathrm{~F}_{0,01}$ \\
\hline $\mathrm{K}$ & $2,82 \operatorname{tn}$ & $2,37 \mathrm{tn}$ & 0,49 tn & $0,71 \mathrm{tn}$ & 0,07 tn & $0,70 \mathrm{tn}$ & 2,90 & 4,50 \\
\hline M & $1,23 \mathrm{tn}$ & $0,02 \mathrm{tn}$ & $0,04 \mathrm{tn}$ & $0,11 \mathrm{tn}$ & $0,65 \mathrm{tn}$ & $0,27 \mathrm{tn}$ & 3,13 & 5,01 \\
\hline $\mathrm{K} \times \mathrm{M}$ & $1,71 \mathrm{tn}$ & $0,29 \mathrm{tn}$ & $0,53 \mathrm{tn}$ & $0,42 \mathrm{tn}$ & $0,57 \mathrm{tn}$ & $0,57 \mathrm{tn}$ & 2,31 & 3,30 \\
\hline
\end{tabular}

HASIL DAN

\section{PEMBAHASAN}

\section{Analisis Parameter Fisiologis Tanaman}

\section{Tinggi Tanaman}

Analisis tinggi tanaman dihitung tujuh minggu pasca tanam disajikan pada Tabel 1.

perlakuan pemberian kompos kulit kopi berpengaruh tidak nyata terhadap tinggi tanaman sejak umur 2 - 7 MST, perlakuan pemberian fungi mikoriza arbuskular tidak berpengaruh terhadap tinggi tanaman sejak umur 2 - 7 MST dan perlakuan kombinasi antara pemberian kompos kulit kopi dan FMA berpengaruh tidak nyata terhadap tinggi tanaman sejak umur 2 - 7 MST. Hasil analisa tanah yang dilakukan di Laboratorium BPTP Sumatera Utara (2019), dengan hasil : C-organik 1,34\%; N 0,19\%; P 9,11 ppm; K 0,27 me/100 g. Selain itu Nilai C- organik tanah yang rendah disebabkan karena sangat kurangnya vegetasi pada tanah penelitian akibat sering diolah untuk dilakukan penanaman dan diangkutnya sisa- sisa panen keluar areal penanaman sehingga terjadi perbedaan terhadap tumbuhnya suatu tanaman (Prabowo dan Subantoro, 2008).

\section{Jumlah Daun}

$$
\begin{aligned}
& \text { Hubungan pemberian pupuk dengan } \\
& \% \mathrm{I}=\frac{\left(95 \mathrm{~N}^{5}+75 \mathrm{~N}^{4}+30 \mathrm{~N}^{3}+5 \mathrm{~N}^{2}+\mathrm{N}^{1}\right)}{\mathrm{N}} \text { petumbuhan tanaman pasca pemberian }
\end{aligned}
$$

\begin{tabular}{|c|c|c|c|c|c|c|c|c|}
\hline \multirow{2}{*}{ SK } & \multicolumn{6}{|c|}{$\mathrm{F}_{\text {Hitung Jumlah Daun }}$} & \multicolumn{2}{|c|}{$\mathrm{F}_{\text {Tabel }}$} \\
\hline & $2 \mathrm{MST}$ & $3 \mathrm{MST}$ & 4 MST & $5 \mathrm{MST}$ & $6 \mathrm{MST}$ & $7 \mathrm{MST}$ & $\mathrm{F}_{0,05}$ & $\mathrm{~F}_{0,01}$ \\
\hline K & $2,70 \mathrm{tn}$ & $1,33 \mathrm{tn}$ & $1,01 \mathrm{tn}$ & $0,44 \mathrm{tn}$ & $0,80 \mathrm{tn}$ & 1,43 tn & 2,90 & 4,50 \\
\hline M & $2,44 \mathrm{tn}$ & $0,34 \mathrm{tn}$ & $0,43 \mathrm{tn}$ & $0,07 \mathrm{tn}$ & $0,77 \mathrm{tn}$ & 0,90 tn & 3,13 & 5,01 \\
\hline $\mathrm{K} \times \mathrm{M}$ & $0,83 \mathrm{tn}$ & $0,44 \mathrm{tn}$ & $0,60 \mathrm{tn}$ & $0,80 \mathrm{tn}$ & $0,35 \mathrm{tn}$ & $0,38 \mathrm{tn}$ & 2,31 & 3,30 \\
\hline
\end{tabular}


Hary Sahputra, Suswati \& Gusmeizal, Suswati (2020) Efektivitas aplikasi kompos kulit kopi dan Fungi mikoriza arbuskular) terhadap produktivitas jagung manis

kompos kulit kopi dan fungi mikoriza arbuskular disajikan pada tabel 2.

Pemberian kompos kulit kopi dan FMA serta kombinasi kedua faktor perlakuan berpengaruh tidak nyata. Pengaruh yang tidak nyata dari pemberian kompos kulit kopi ini disebabkan kandungan hara yang dihasilkan dari dekomposisi kulit kopi setelah diaplikasikan pada tanah masih tergolong rendah. Ketersediaan unsur hara tanah di daerah tropis tidak dapat mencukupi kebutuhan tanaman untuk pertumbuhan dan produksi, sehingga perlu penambahan pupuk sebagai sumber unsur hara. Proses perombakan atau dekomposisi bahan organik menjadi zat organik berbentuk ion tersedia bagi tanaman umumnya berlangsung relatif lama sekitar 2 sampai 3 bulan, sedangkan pemberian bahan organik yang belum terdekomposisi sempurna dapat berakibat negatif bagi tanaman karena dalam proses tersebut akan terjadi persaingan antara mikroorganisme dengan tanaman untuk mendapatkan nutrisi di dalam tanah. Untuk mengatasi hal tersebut dapat digunakan bioaktivator seperti Effective Microorganism 4 (EM4) yang menyebabkan bahan organik akan terdekomposisi dalam waktu yang cepat yaitu sekitar 1-2 minggu.

\section{Panjang Tongkol}

Pengaruh aplikasi pupuk kulit kopi dengan fungi mikoriza disajikan pada tabel 3.

Table 3. Hasil Sidik Ragam Panjang Tongkol Tanaman Jagung Manis Setelah Aplikasi Kompos Kulit Kopi dan Fungi Mikoriza Arbuskular serta Kombinasi Kedua Faktor Perlakuan

\begin{tabular}{cccc}
\hline \multirow{2}{*}{$\mathrm{SK}$} & \multirow{2}{*}{$\mathrm{F}_{\text {Hitung }}$} & \multicolumn{2}{c}{$\mathrm{F}_{\text {Tabcl }}$} \\
\cline { 3 - 4 } & $0,80 \mathrm{tn}$ & $\mathrm{F}_{0,05}$ & $\mathrm{~F}_{0,01}$ \\
\hline $\mathrm{K}$ & $0,43 \mathrm{tn}$ & 2,90 & 4,50 \\
$\mathrm{M}$ & $1,18 \mathrm{tn}$ & 3,13 & 5,01 \\
$\mathrm{~K} \mathrm{x} \mathrm{M}$ & 2,31 & 3,30 \\
\hline
\end{tabular}

Keterangan: Angka yang diikuti oleh huruf yang sama pada kolom yang sama berbeda tidak nyata pada taraf $\alpha 0.5$ (huruf kecil) dan $\alpha 0.1$ (huruf besar) berdasarkan Uji Jarak Duncan. tn $=$ tidak nyata, $*=$ nyata, $* *=$ sangat nyata.

Faktor perlakuan pemberian kompos kulit kopi dan FMA serta kombinasi kedua faktor perlakuan berpengaruh tidak nyata terhadap panjang tongkol jagung manis. Berdasarkan kriteria kandungan hara pada tanah yang ditetapkan oleh Balai Penelitian Tanah Bogor (2009), keadaan tanah tempat penelitian ini tergolong pada tanah yang unsur haranya rendah. Selain rendahnya kandungan hara pada tanah, $\mathrm{pH}$ tanah juga tergolong masam, yakni 4,75. Pada parameter panjang tongkol menunjukkan bahwa perlakuan faktor pemberian kompos kulit kopi dan FMA serta kombinasi kedua faktor perlakuan tidak berpengaruh nyata pada pertumbuhan tanaman hal ini dapat juga disebabkan oleh faktor lingkungan. Jagung akan tumbuh dengan baik dengan iklim yang ideal untuk tanaman jagung seperti suhu dengan kisaran $24^{\circ} \mathrm{C}$ sedangkan kebutuhan curah hujan yang dibutuhkan adalah sekitar 85 - $100 \mathrm{~mm}$ per bulan namun berdasarkan data dari stasiun klimatologi Deli Serdang menunjukkan bahwa suhu selama penelitian 
berkisar 27 - 28 $\mathrm{C}$ serta curah hujan berkisar $193 \mathrm{~mm}$ per bulan, hal ini diduga penyebab kurang baiknya pembentukan buah tanaman jagung.

\section{Analisis Parameter Produksi}

Hasil sidik ragam pengaruh pemberian kompos kulit kopi dan FMA serta kombinasi kedua faktor perlakuan terhadap bobot basah bagian atas tanaman jagung manis dapat dilihat pada Tabel 4.

Table 4. Sidik Ragam Bobot Basah Bagian Atas Tanaman Jagung Manis Setelah Aplikasi Kompos Kulit Kopi dan Fungi Mikoriza Arbuskular serta Kombinasi Kedua Faktor Perlakuan serta Kombinasi Kedua Faktor Perlakuan

\begin{tabular}{cccc}
\hline \multirow{2}{*}{$\mathrm{SK}$} & $\mathrm{F}_{\text {Hitung }}$ & $\mathrm{F}_{0,05}$ & $\mathrm{~F}_{\text {Tabel }}$ \\
\cline { 3 - 4 } & & 2,90 & $\mathrm{~F}_{0,01}$ \\
$\mathrm{~K}$ & $1,50 \mathrm{tn}$ & 3,13 & 5,50 \\
$\mathrm{M}$ & $0,30 \mathrm{tn}$ & 2,31 & 3,30 \\
$\mathrm{~K} \times \mathrm{M}$ & $1,66 \mathrm{tn}$ & \multicolumn{2}{c}{} \\
Keterangan: Angka yang diikuti oleh huruf yang sama pada kolom yang sama berbeda tidak nyata \\
pada taraf $\alpha 0.5$ (huruf kecil) dan $\alpha 0.1$ (huruf besar) berdasarkan Uji Jarak Duncan. tn \\
= tidak nyata, ${ }^{*}=$ nyata, ${ }^{* *}=$ sangat nyata.
\end{tabular}

pemberian kompos kulit kopi berpengaruh tidak nyata, pemberian FMA berpengaruh tidak nyata dan kombinasi antara pemberian kulit kopi dengan FMA berpengaruh tidak nyata terhadap bobot basah bagian atas tanaman jagung manis. Menurut Talanca (2010), bahwa fungi mikoriza arbuskular mempunyai struktur yang terdiri dari hifa yang tidak bersekat, dan tumbuh diantara sel korteks dan didalamnya bercabang, tetapi tidak masuk sampai jaringan stele (silinder pusat, bagian terdalam dari akar). Artinya, mikoriza tidak sampai menginfeksi bagian struktur dalam akar, tetapi hanya sampai bagian struktur luar dari sistem perakaran.

Mikoriza tidak secara langsung membantu pertumbuhan bagian tanaman yang spesifik, tetapi mikoriza merupakan mikroorganime perantara pertumbuhan tanaman dengan menyediakan suplai untuk mengambil nutrisi di dalam tanah yang biasanya tidak dapat dijangkau oleh tanaman ketika tanpa adanya mikoriza. Selanjutnya, bagian tanaman yang memiliki fungsi tersendiri yang mengalirkan dan meneruskan ke seluruh bagian tanaman lainnya.

Hasil sidik ragam pengaruh pemberian kulit kopi dan fma serta kombinasi kedua faktor perlakuan terhadap bobot basah bagian bawah tanaman jagung manis tidak memberikan pengaruh nyata. pemberian FMA berpengaruh tidak nyata dan kombinasi antara pemberian kompos kulit kopi dengan FMA berpengaruh tidak nyata terhadap bobot basah bagian bawah tanaman jagung manis. Mikoriza tidak mampu beradaptasi pada tanaman yang tercekam oleh faktor biotik seperti serangan patogen tanaman.

Data hasil sidik ragam pengaruh pemberian kompos kulit kopi dan fma serta kombinasi kedua faktor perlakuan terhadap produksi sampel per plot tanaman jagung manis dapat dilihat pada Tabel 5. 
Hary Sahputra, Suswati \& Gusmeizal, Suswati (2020) Efektivitas aplikasi kompos kulit kopi dan Fungi mikoriza arbuskular) terhadap produktivitas jagung manis

Table 2. Sidik Ragam Produksi per Plot Tanaman Jagung Manis Setelah Aplikasi Kompos Kulit Kopi dan FMA serta Kombinasi Kedua Faktor Perlakuan

\begin{tabular}{cccc}
\hline SK & \multirow{2}{*}{ F Hitung } & $\mathrm{F}_{0,05}$ & $\mathrm{~F}_{\text {Tabel }}$ \\
\cline { 3 - 4 } $\mathrm{K}$ & $1,43 \mathrm{tn}$ & 2,90 & 4,50 \\
$\mathrm{M}$ & $2,00 \mathrm{tn}$ & 3,13 & 5,01 \\
$\mathrm{~K} \mathrm{x} \mathrm{M}$ & $1,18 \mathrm{tn}$ & 2,31 & 3,30 \\
\hline Keterangan: Angka yang diikuti oleh huruf yang sama pada kolom yang sama berbeda tidak nyata \\
pada taraf $\alpha 0.5$ (huruf kecil) dan $\alpha 0.1$ (huruf besar) berdasarkan Uji Jarak Duncan. tn \\
= tidak nyata, ${ }^{*}=$ nyata, $^{* *}=$ sangat nyata.
\end{tabular}

Pemberian kompos kulit kopi dan FMA serta kombinasi kedua faktor perlakuan berpengaruh tidak nyata. Tidak nyatanya pemberian kompos kulit kopi diduga disebabkan adanya penyakit layu stewart (Pantoea stewartii) yang menyerang pada tanaman jagung hal ini juga penyebab kurang baiknya pertumbuhan tanaman jagung sehingga tidak memberikan pengaruh terhadap produksi tanaman. Gejala penyakit layu stewart yang ditemukan pada beberapa sentra pertanaman jagung di Sumatera Barat sangat beragam. Gejala penyakit sesuai dengan yang dikemukakan oleh Rahma (2014), yaitu daun-daun bagian bawah awalnya memiliki garis-garis berwarna kuning. Penyakit ini berbeda dengan penyakit hawar yang umumnya menyebabkan warna daun-daunnya berkembang menjadi hijau pucat sampai kuning, terdapat garis longitudinal, dengan pinggiran tidak teratur atau bergelombang, dan dapat memanjang di sepanjang helaian daun, garis-garis ini mengering kemudian bewarna cokelat.

Kondisi pH tanah juga menentukan perkembangan mikroorganisme dalam tanah. Pada pH 5,5 - 7 jamur dan bakteri pengurai bahan organik akan tumbuh dengan baik. Demikian juga mikroorganisme yang menguntungkan bagi akar tanaman juga akan berkembang dengan baik (Maspury, 2011).

Persentase Serangan Organisme Pengganggu Tanaman (OPT) Pada Tanaman

\section{Jagung Manis}

Hama penggerek tongkol jagung yang menyerang tanaman jagung manis pada saat penelitian tidak ditemukan. Hal ini disebabkan karena pemberian kompos kulit kopi dan fungi mikoriza arbuskular mampu menekan tingkat serangan hama penggerek tongkol jagung tersebut. Selain itu, Penyakit layu Stewart tergolong sulit dikendalikan karena menyerang tanaman pada fase pertumbuhan, bersifat tular benih dan tular serangga. Sampai saat ini usaha pengendalian penyakit ini masih menggunakan insektisida sintetis yang mengandung imidachlopriod untuk seed treatment, namun dikhawatirkan penggunaan bahan ini akan mempercepat pencemaran lingkungan. Adapun gejala penyakit layu Stewart pada sampel diperlihatkan pada gambar 1 . 


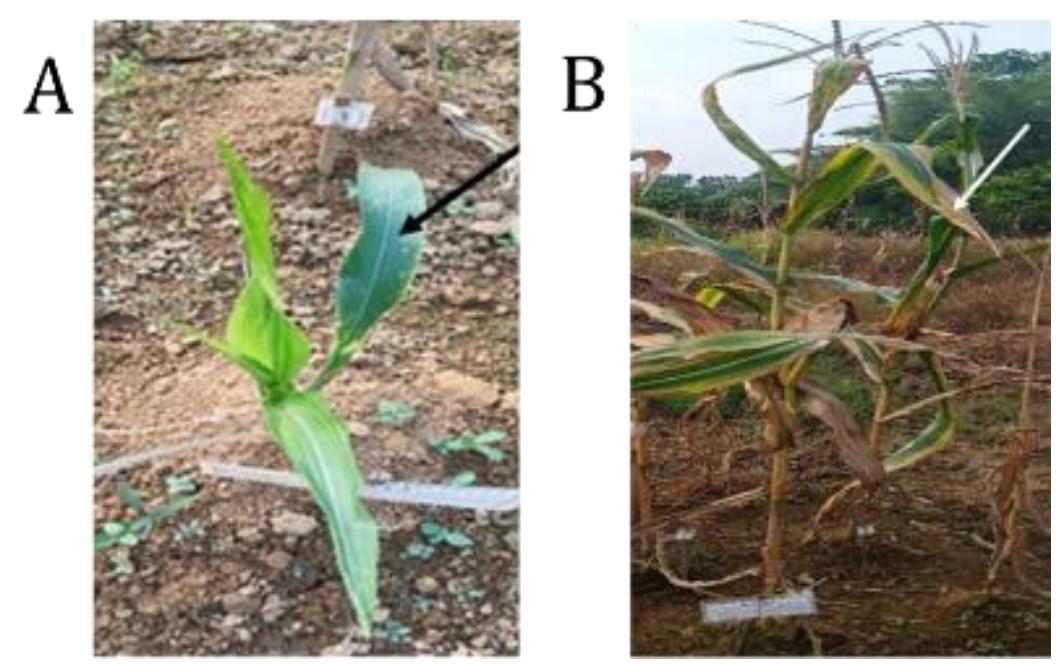

Gambar 1. Penyakit Layu Stewart yang Menyerang Tanaman Jagung Manis Umur 9 MST.

Secara umum penyakit layu Stewart terdiri atas 2 fase : pertama terjadi pada tanaman muda (Gambar 1A) dan yang kedua terjadi pada tanaman dewasa terutama setelah munculnya malai (Gambar 1B). Pada tanaman muda luka water soaking yang panjang terdapat disepanjang daun. Daun memperlihatkan garis hijau pucat sampai kuning pada fase kedua dari penyakit Stewart terjadi setelah munculnya malai. Infeksi hanya bersifat lokal. Umumnya gejala berupa bercak pada daun, bercak berupa goresan hijau sampai kuning dengan pinggiran yang tak beraturan dan bergelombang disepanjang tulang daun dan juga diseluruh permukaan daun (Stack et al, 2006).

Kolonisasi Fungi Mikoriza Arbuskular

Data pengamatan persentase akar tanaman pada produksi jagung manis memeriksa bahwa semua perlakuan menunjukkan telah terkolonisasi oleh mikoriza. Analisis mikroskopik tehadap kolonisasi FMA diperlihatkan pada Gambar 2.
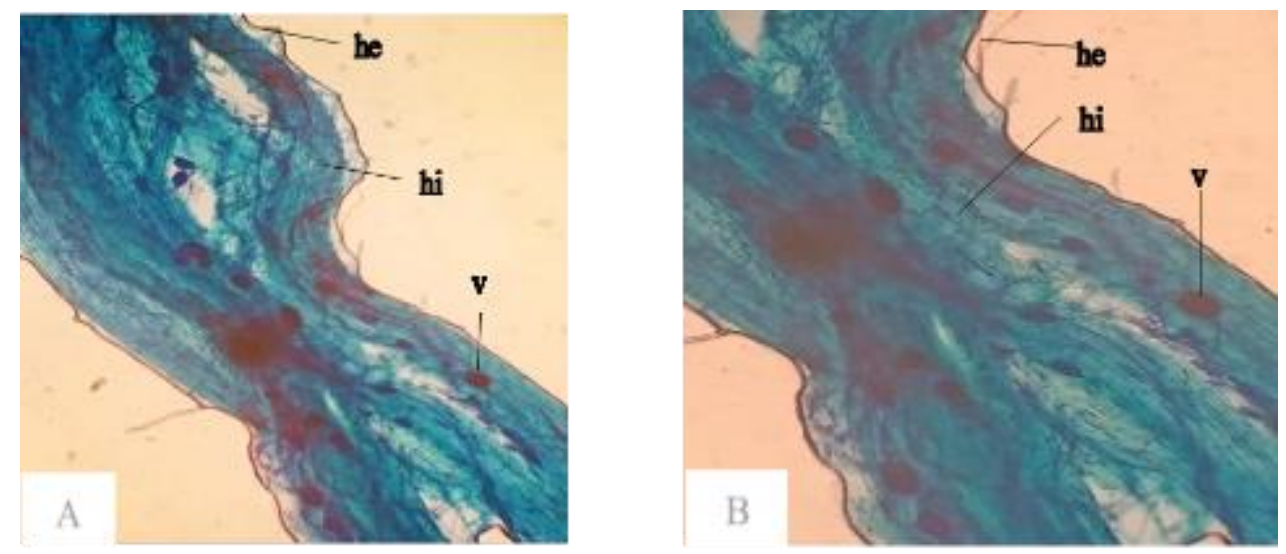

Figure 1. Hasil Pengamatan Akar yang Terkolonisasi Fungi Mikoriza Arbuskular: A. Perlakuan K0M2, B. Perlakuan K4M3. Keterangan: 1. he $=$ Hifa eksternal, 2. hi $=$ Hifa internal, 3. v = Vesikular

Akar yang terkolonisasi oleh FMA sangat bervariasi, kolonisasi FMA terjadi kenaikan pada perlakuan K0M0 dengan K3M3. P0M0 merupakan perlakuan yang terendah pada parameter kolonisasi FMA yaitu (50\%) dan terjadi peningkatan pada perlakuan lainnya. Perlakuan K3M3 merupakan perlakuan yang tertinggi dengan tingkat 
Hary Sahputra, Suswati \& Gusmeizal, Suswati (2020) Efektivitas aplikasi kompos kulit kopi dan Fungi mikoriza arbuskular) terhadap produktivitas jagung manis

persentase FMA yaitu 100\%. Semua perlakuan yang tertinggi pada produksi jagung manis menunjukkan akar yang terkolonisasi oleh FMA meningkat di semua perlakuan.

\section{SIMPULAN}

Pemberian kompos kulit kopi untuk semua dosis yang diberikan (10 - 30 ton $\mathrm{ha}^{-1}$ ) pada saat tanam tidak berpengaruh nyata terhadap parameter tinggi tanaman, jumlah daun, panjang tongkol, produksi sampel per plot, produksi per plot, bobot basah bagian atas dan bobot basah bagian bawah tanaman jagung manis. Pemberian fungi mikoriza arbuskular untuk semua dosis yang diberikan $(10-20 \mathrm{~g} /$ plot $)$ pada saat tanam tidak berpengaruh nyata terhadap parameter tinggi tinggi tanaman, jumlah daun, panjang tongkol, produksi sampel per plot, produksi per plot, bobot basah bagian atas dan bobot basah bagian bawah tanaman jagung manis. Pemberian kombinasi kompos kulit kopi dan fungi mikoriza arbuskular untuk semua dosis yang diberikan pada saat tanam tidak berpengaruh nyata terhadap parameter tinggi tanaman, jumlah daun, panjang tongkol, produksi sampel per plot, produksi per plot, bobot basah bagian atas dan bobot basah bagian bawah tanaman jagung manis.

\section{DAFTAR PUSTAKA}

Andi, (2013). Tanaman Jagung Manis (Sweet corn). Diakses di Pengaruh Konsentrasi dan Waktu Pemupukan POC Super ACI terhadap Pertumbuhan dan Hasil Jagung Manis. Fakultas Pertanian Universitas Tujuh Belas Agustus 1945 Samarinda.

Balai Penelitian Tanah. Bogor. (2009). Analisis Kimia Tanah, Tanaman, Air dan Pupuk.

Hanafiah KA. (2005). Dasar Dasar Ilmu Tanah.

Manullang, W., Astuti K., R., \& Pane, E. (2017). Pengaruh Pemberian Bahan Organik Kulit Biji Kopi Dan Zat Perangsang Tumbuh Hydrasil Pada Pertumbuhan Bibit Karet Okulasi Klon PB 260. Agrotekma:

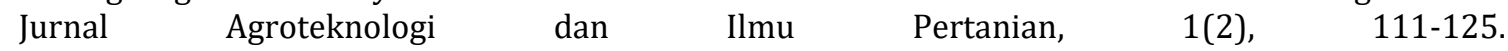
doi:https://doi.org/10.31289/agr.v1i2.1129

Mardatin N. (2002). Aplikasi Cendawan Mikoriza Arbuskular (CMA) pada Beberapa Spesies Tanaman Kehutanan, Prosiding Hasil-hasil Litbang Rehabilitasi dan Konservasi Sumberdaya Hutan. Puslitbang Hutan dan Konservasi Alam. Bogor, 79-83.

Maspury. (2011). Mengatasi Tanah Masam dan Basa. http://www.gerbangpertanian.com /2011/11/mengatasi-tanah-masam-dan-basa.html. Diakses pada tanggal10 Juli 2019.

Permadi, M., \& Harahap, Q. (2019). Tingkat dan Pola Distribusi Infestasi Penggerek Batang Jagung Ostrinia Furnacalis (Lepidoptera: Crambidae) Di Padangsidimpuan. Biolink : Jurnal Biologi Lingkungan Industri Kesehatan, 6(1), 25 - 31. doi:https://doi.org/10.31289/biolink.v6i1.2093

Prabowo R, \& Subantoro R. (2018). Analisis tanah sebagai indikator tingkat kesuburan lahan budidaya pertanian di Kota Semarang. CENDEKIA EKSAKTA, 2(2).

Reavindo, Q., \& Br Bangun, R. (2016). PENGARUH LUAS PANEN DAN HARGA PRODUKSI TERHADAP PRODUKSI TANAMAN JAGUNG KABUPATEN KARO. JURNAL AGRICA, 9(1), $74 \quad$ - 79. doi:https://doi.org/10.31289/agrica.v9i1.401

Setiawati M, Fitriantin B, \& Suryatman P. (2000). Pengaruh Mikoriza dan Pupuk Fosfat terhadap Derajat Infeksi Mikoriza dan Komponen Pertumbuhan tanaman Kedelai. Paper presented at the Prosiding Seminar Nasional Mikoriza I. Bogor.

Setya, R., Kuswardani, R., \& Pane, E. (2019). Analisis Usahatani Jagung (Zea Mays L.) dan Efisiensi Pemasaran di Kecamatan Pangkatan Kabupaten Labuhanbatu terhadap Peningkatan Pendapatan Masyarakat. AGRISAINS: Jurnal Ilmiah Magister Agribisnis, 1(2), 152-161.

Suswati S, Najril N, \& Azwana A. (2013). Peningkatan Ketahanan Tanaman Pisang Barangan Terhadap Blood Disease Bacterium (BDB) Dengan Aplikasi Fungi Mikoriza Arbuskular Indigenus. Jurnal Hama dan Penyakit Tumbuhan Tropika, 13(1), 96-104. 
Talanca H. (2010). Status Cendawan Mikoriza Vesikular Arbuskular (MVA) Pada Tanaman. Prosiding Pekan Serealia Nasional, 353-357.

Widyotomo S. (2013). Potensi dan teknologi diversifikasi limbah kopi menjadi produk bermutu dan bernilai tambah. Penelitian Kopi dan Kakao, 1(1), 63-80. 